\title{
Diyabetik Ayağın İyileşmesinde Beslenme Tedavisinin Rolü Var mı?
}

\author{
Does Nutritional Therapy Have a Role in the Recovery of Diabetic Foot?
}

\section{Selda Seçkiner ${ }^{1}$}

Geliş tarihi/Received: 03.09.2019 • Kabul tarihi/Accepted: 07.11.2019

\section{ÖZET}

Tüm dünyada diyabetli hasta sayısı giderek artmakta ve buna eşlik eden komplikasyonların özellikle de diyabetik ayak ülseri (DAÜ) insidansı artmaktadır ki diyabet ile ilişkili ayak komplikasyonları en yaygın morbidite sebebidir. DAÜ’ye bağlı komplikasyonların yıllık insidansı \%2'dir. DAÜ’nin tedavisi ve izlemi, hastanın yaşam kalitesinin arttırılması, infeksiyonun kontrol edilmesi, ampütasyon riskinin azaltılması ve ülkede ekonomik yükünün azaltması gibi sebeplerden dolayı önemlidir. Etkin diyabet yönetimi ile DAÜ komplikasyonlarını geciktirmek veya önlemek mümkündür. Tedavi ve önlemde ki hedefler; hasta eğitimi, iyi metabolik kontrol, risk faktörleri olan hastaların saptanması ve tedavisidir. Diyabetli bireyde yara iyileşmesi bozulmuştur. DAÜ, inflamatuvar cevabın uzaması, matriks yenilenmesinin gecikmesi ile karakterizedir. DAÜ’nün iyileşmesinin gecikmesi, tekrarlayan infeksiyonların varlığı, hastaneye yatış sıklığının artması morbidite ile ilişkilidir. Bu başarısızlığı önlemek için tedavide multidisipliner yaklaşım önemlidir. DAÜ’de yara iyileşmesinde glisemik kontrolü sağlamak için medikal tedavilerle birlikte tıbbı beslenme tedavisi gerekmektedir. Beslenme tedavisindeki önceliğin ve beslenme desteği gereksiniminin belirlenmesinde beslenme durumunun değerlendirilmesi önem taşımaktadır. Besin ögelerinin alımının yetersiz olması inflamatuvar sürecin uzamasına, fibroblast proliferasyonunun azalmasına ve kollajen sentezinin bozulmasına neden olarak yara iyileşmesini geciktirmektedir. Malnutrisyon varlığı da yara iyileşmesini olumsuz etkiler. DAÜ’lü hastaların \%84.8'inde beslenme durumunun bozulmuş olduğu gösterilmiştir. DAÜ’nün şiddeti ve bununla ilişkili inflamatuvar yanıt, besin ögesi eksikliklerini şiddetlendiren negatif protein metabolizmasıyla ilişkilidir. Optimal beslenmedeki amaç yara iyileşmesinin sağlanmasıdır. Beslenme durumunun düzeltilmesinde enerji, makro ve mikro besin ögeleri eksiğinin tamamlanması yara iyileşme sürecini olumlu etkilemektedir. Besin ögesi takviyesi tamamlayıcı terapötik bir önlem olabilir. DAÜ’leri tedavi etmek için kanıta dayalı bir kılavuz bulunmamaktadır. Bağışıklık fonksiyonunu etkileyen, yetersiz beslenme ve kötü glisemik kontrole neden olan risk faktörleri beslenme tedavisi ile iyileştirilebilir. Sonuç olarak, yeterli enerji, protein, vitamin ve mineral alımı sağlayan beslenme tedavisi, bağışıklık fonksiyonunu en üst düzeye çıkarmaya yardımcı olabilir. DAÜ’lü hastalar sağlıklı beslenmeye teşvik edilmelidir.

Anahtar kelimeler: Diyabet, ayak ülseri, malnutrisyon, beslenme tedavisi, besin ögesi

\section{ABSTRACT}

The number of patients with diabetes is increasing all over the world, also complications especially the incidence of diabetic foot ulcers are increasing, which is the most common cause of morbidity. The annual incidence of complications related to diabetic foot ulcer (DFU) is $2 \%$, and DFU occurs in diabetic patients at least once in their life. DFU's treatment and followup is important for increasing the quality of life of the patient, controlling infection, reducing the risk of amputation and reducing the economic burden in the country. In addition, with careful management, it is possible to delay or prevent DFU,

1. İletişim/Correspondence: Ege Üniversitesi Tıp Fakültesi Hastanesi İç Hastalıkları Anabilim Dalı, İzmir, Türkiye

E-posta: seldaseckiner@yahoo.com.tr • $\odot$ https://orcid.org/0000-0002-5899-4998 
patient education, good metabolic control, detection and treatment of patients having risk factors are goals of treatment and prevention. Diabetic wound is characterized by prolonged inflammatory response, delayed matrix regeneration. The results of DFU such as, recurrent infections, and frequency of hospitalization are associated with morbidity. In order to prevent this complication, a multidisciplinary assessment is important. Medical nutrition therapy is required along with medical therapies in order to provide glycemic control in wound healing in DFU. It is important to evaluate the nutritional status in order to determine the priority in nutritional therapy and the need for nutritional support. Inadequate nutrient intake leads to prolonged inflammatory process, decreased fibroblast proliferation, and collagen synthesis, thus delaying wound healing. Malnutrition also causes adverse effects in wound healing. In $84.8 \%$ of DFU patients showed impaired nutritional status. The severity of DFU is associated with negative protein metabolism that exacerbates nutrient deficiencies. Optimal nutrition provides good wound healing. Completion of energy, macro and micronutrients in the correction of nutritional status positively affects the wound healing process. There is no evidence-based guideline for treating DFUs. As a result, nutrition therapy that provides enough energy, protein, vitamins and minerals can help to maximize immune function. Patient with DFU should be encouraged to eat a healthy diet.

Keywords: Diabet, foot ulcers, malnutrition, nutrition therapy, nutrient

\section{GíRiş}

Diabetes mellitus, insülin salgısında ve/veya etkisinde bozukluk sonucu oluşan, organizmanın karbonhidrat, protein ve yağlardan yeterince yararlanamadığı ve hiperglisemi ile seyreden bir grup metabolik bozukluktur. Uluslararası Diyabet Federasyonu (International Diabetes Federation [IDF])'nun 2017 verilerine göre dünya genelinde diyabetli sayısı 425 milyondur. Diyabet prevalansında ki artışa paralel olarak komplikasyon görülme sıklığı da artmaktadır. Diyabetin komplikasyonlarından biri olan diyabetik ayak ülserleri (DAÜ) en yaygın morbidite sebebidir. DAÜ’ye bağlı komplikasyonların ylllı insidansı $\% 2$ oranındadır, diyabetlilerin \%15'inde en az bir kez DAÜ gelişmekte ve \%66 oranında hastaneye yatış görülmektedir (1,2). Bu derlemede diyabetik ayak ülserinde beslenme tedavisinin rolü ve önemi irdelenecektir.

\section{Diyabetik Ayak Ülseri}

DAÜ tanısında pek çok sınıflama yöntemi bulunmaktadır. DAÜ’nün günümüzde en sık kullanılan Wagner sınıflamasına göre değerlendirilmesi aşağıda verilmiştir (3).

DAÜ periferik nöropati, bacaktaki arter hastalığı ve infeksiyon birlikteliğinden meydana gelmektedir (1). Nörolojik dejenerasyon, vaskülopati, iyi kontrol altına alınmamış infeksiyon, bozuk kollajen üretimine bağlı olarak kötü yara iyileşmesi yıkıcı sürece neden olan farklı mekanizmalardır. Bu faktörler ayağın sinir donanımını (innervasyonunu), beslenmesini, ayak bütünlügünün sürdürülmesini etkiler (4). Yara iyileşmesi travmadan hemen sonra başlayan, hemostaz, inflamasyon (1-4 gün), poliferasyon (2-22 gün), maturasyon (6-12 ay) fazlarını içeren dinamik bir süreçtir (5-8). Travma dokunun yapısını bozar,

Tablo 1. Diyabetik ayak ülserlerinde Wagner sınıflaması (3)

\begin{tabular}{ll}
\hline Evre & Belirtiler \\
\hline Evre 0 & Ülser yok ama ülser yönünden risk altındadır. \\
Evre 1 & Derinin veya subkutan dokunun yüzeysel ülseri var, infeksiyon yok. \\
Evre 2 & $\begin{array}{l}\text { Tendon, kemik veya eklem kapsülüne ulaşan derin ve penetran ülser var, sıklıkla infeksiyon var, abse veya } \\
\text { kemik tutuluşu yok. }\end{array}$ \\
Evre 3 & Osteomyelit veya absenin de eşlik ettiği derin ülser mevcut. \\
Evre 4 & Lokalize gangren (parmak, ayakucu, topuk) var. \\
Evre 5 & Ayağın büyük bölümünde gangren var. \\
\hline
\end{tabular}


kanamaya neden olur ve bunu hemostaz izler. Yaralanma ile birlikte damarlar açılır ve açığa çıkan subendotelial kollajene trombositlerin adezyon ve agregasyonu sonucu pıhtılaşma süreci başlar. Ayrıca trombositler, sitokinleri ve büyüme faktörlerini salgılar. Oluşan pıhtı buraya gelecek olan nötrofil, monosit, fibroblastlar için bir yapı iskelesi görevi görür. İnflamasyon, artmış vasküler geçirgenlik ve prostaglandinlerle birlikte kemotaktik faktörler (kompleman, interlökin-1, tümör nekroz faktörTNF, transporting growth faktör-TGF, bakteri yıkım ürünleri) salınır, yaraya çeşitli hücreler göç eder. Ayrıca makrofajlar sitokinler aracılığı ile lenfositleri, nitrik oksit aracılığı ile monosit, fibroblast ve endotel hücrelerini aktive eder (9,10). Proliferasyon fazl, anjiogenez, kollajen üretimi ve depolanması, yara kontraksiyonu ile karakterizedir. Endotel hücrelerin proliferasyonu yeni damarların oluşumunu, fibroblastlarin proliferasyonu ise yeni kollajen oluşumunu ve yara bölgesindeki granülasyon dokusunun oluşumunu destekler $(9,10)$. Remodelling, yara iyileşmesinin erken döneminde keratinositler ortaya çlkarak reepitelizasyonu başlatır. Böylece kayıp dokunun yerine yeni granüle doku oluşmaya başlar. Fazın en önemli özelliği yarada kollajen birikimidir. Maturasyon uzun bir süreçtir. Yaranın mekanik gücünün arttığı bir dönemdir, üç ay sonra normal gerilme gücünün yaklaşık \%80’ne ulaşır $(9,10)$.

Yara iyileşmesini olumsuz etkileyen faktörler lokal ve sistemik olarak iki şekilde sınıflandırılmaktadır. Ateroskleroza sekonder periferik atardamar hastalığı, vaskülit-venöz yetmezlik, uzun süreli basınç, doku fibrozis, yabancı cisim lokal faktörlerdendir. Beslenme, yaş, ilaçlar (kemoterapötikler, steroidler, steroid olmayan antiinflamauvar ilaçlar), iskemi, sigara, radyasyon, ödem, diyabet, immün yetmezlik, renal yetmezlik, üremi, karaciğer hastalığı ve/veya yetmezliği sistemik faktörlerdendir. (11-15).

DAÜ’lü hastanın tedavisi ve izlemi, yaşam kalitesini arttırmak, infeksiyonu kontrol etmek, ampütasyon riskini azaltmak ve ekonomik yükü azaltmak gibi sebeplerden dolayı önemlidir (11). Diyabetik ayak ülserlerinin yıllık insidansı \%1-4 civarındadır. Travmatik olmayan alt ekstremite ampütasyonlarının yaklaşık \%50'sini diyabetli bireylerin oluşturduğu ve bu hastalarda ampütasyon sonrası mortalite oranının beş yllda \%39-80 arasında değiştiği bildirilmiştir (16). Her ne kadar ayak ülserinin alt ekstremite ampütasyonu ile birlikteliği daha az oranda görülse de bu ampütasyonlar yüksek maliyet ile ilişkilidir. EURODIALE (European Study Group on Diabetes and the Lower Extremity) çalışmasında, 2003 yılı Avrupa diyabet sıklığı ve komplikasyonları verilerine dayanarak DAÜ’nün tedavisi ile ilişkili maliyetlerin yllda 10 milyar avroya kadar yükselebileceği öngörülmüştür (17).

Tedavinin dikkatli yönetilmesi ile DAÜ’nün komplikasyonlarını geciktirmek veya önlemek mümkündür. DAÜ’nün önlenmesi için diyabetli bireylerin eğitimi, metabolik kontrolün sağlanması, diyabetik ayak için risk faktörlerine sahip olan hastaların saptanması ve tedavisi hedeflenmelidir (3). Potansiyel temel sorunları için multidisipliner bir yaklaşım önerilmektedir. Diyabet eğitimi tüm DAÜ'lerin tedavisinde yer almalıdır. Akut/kronik ve akut/acil DAÜ’lerde glisemik kontrolü sağlamak için medikal tedavilerle birlikte tıbbı beslenme tedavisi (TBT) de gerekmektedir (18).

\section{Diyabetik Ayak Ülseri Gelişmiş Hastalarda Tıbbi Beslenme Tedavisi}

Yetersiz beslenme potansiyel olarak geri dönüşümlüdür, erken dönemde tanımlanması oldukça önemlidir. Bozulmuş nutrisyonel durumda azalmış anabolizma, artmış katabolizma ve kronik yara oluşumu gözlenmektedir (1). Yara iyileşmesinde ortamda var olan besinsel substratlar önemlidir. Kronik bir yara altı haftadan daha uzun bir süre iyileşmemiş yaradır ve iyileşmesi kötü beslenme, dehidrasyon ve infeksiyon birlikteliği ile komplike hale gelmektedir. Bireyin beslenme ve hidrasyon durumu doku canlılığının korunmasında, hasar durumunda doku tamirinin desteklenmesinde ve yara bakımının yönetiminde önemli bir rol oynar (19). 
Diyabetli bireyde yara iyileşmesi bozulmuştur. DAÜ, inflamatuvar cevabın uzaması, matriks yenilenmesinin gecikmesi ile karakterizedir. DAÜ’nün iyileşmesindeki gecikmeler, tekrarlayan infeksiyonların varlığı ve hastaneye yatış sıklığının/ süresinin artması morbiditeyle ilişkilidir. Bunu önlemek için beslenme yetersizliğinin değerlendirilmesi, nütrisyon desteğine yanıt veren hastanın ve ülserasyon özelliklerinin anlaşılması, destek tedavisinin optimal süresinin saptanması önemlidir. Beslenme durumunun düzeltilmesinde besin ögesi takviyesi tamamlayıcı terapötik bir önlem olabilir (20).

\section{Beslenme Durumunun Değerlendirilmesi}

Besin ögelerinin alımının yetersiz olması inflamatuvar sürecin uzamasına, fibroblast proliferasyonunun azalmasina ve kollajen sentezinin bozulmasina neden olarak yara iyileşmesini geciktirmektedir. Malnutrisyon varlığı da yara iyileşmesini olumsuz etkilemektedir. Uygun beslenme desteği tıbbı bakımın yaşamsal parçasıdır. Beslenme durumu komplikasyonların gelişimi, hastanede kalış süresi, yaşam beklentisi ve diğer sonuçlarla belirgin olarak ilişkilidir ve buna eşlik eden diyabetin varlığı ile bu faktörler daha da ilerler (21-23). Bir çalışmada, Wagner sınıflamasına göre evre 1-5 arası 192 DAÜ’lü hasta ile Wagner'e göre evre 0 olan 60 hastada sübjektif global değerlendirme (SGA), biyokimyasal parametreler, antropometrik ölçümler değerlendirilmiş, tüm DAÜ’lü hastaların \%62'sinde malnütrisyon saptanmıştır. SGA ile infeksiyon arasında ilişkinin anlamlı olduğu bildirilmiştir. Dolayısıyla nutrisyonel durum yara iyileşme şiddetini bozabilir ve infeksiyonun şiddeti kötü prognozun göstergesi olabilir. DAÜ’nün vasküler komplikasyonlar ve infeksiyonla birlikteliğinde beslenme durumunun bozulduğu ve şiddetin artması ile nutrisyonel risk derecesinin daha da arttığ ve mortalite ile ilişkili olduğu gösterilmiştir $(4,24)$.

Malnutrisyonun tanımlanması, TBT için uygun hastanın belirlenmesi ve vücut ağırlığı veya yağsız vücut kütlesinden hangisinin korunmasının hedef alınacağının bilinmesi önemlidir (25). Avrupa Klinik
Beslenme ve Metabolizma Derneği (European Society Parenteral Enteral Nutrition [ESPEN]), malnütrisyon tanısı konulabilmesi için, malnutrisyon riskine sahip bireylerin öncelikli olarak tanımlanmasını, mevcut tabloya göre değerlendirilmesini ve tedavi edilmesini önerir. Bunun için ESPEN geçerliliği tanımlanmış tarama ölçütlerinin kullanılması gerektiğini bildirmiştir. Malnütrisyon tanısı iki kriterin varlığını gerektirir. Birincisi Dünya Sağlık Örgütü'nün (World Health Organisation [WHO]) düşük vücut ağırlığı olarak kabul ettiği < $18.5 \mathrm{~kg} / \mathrm{m}^{2}$ beden kütle indeksi (BKİ) değerinin olması, ikincisi istemsiz vücut ağırlık kaybı ve azalmış BKİ veya düşük yağsız vücut kütle indeksinden (FFM) en az birisinin ilk kritere eşlik etmesidir. Benzer şekilde Amerika Parenteral ve Enteral Beslenme Derneği (American Society Parenteral Enteral Nutrition [ASPEN]) yetişkinlerde malnutrisyon tanısı koymak için, düşük enerji alımı, vücut ağırlığı kaybı, kas kütlesi kaybı, subkütan yağ kaybı, sıvı birikimi, el kavrama gücü gibi altı malnütrisyon kriterinden en az ikisinin varlığının gerekli olduğunu bildirmiştir (26-28). ESPEN malnutrisyon taramasinın ilk görüşmeyi izleyen 24-48 saat içerisinde yapılmasını ve daha sonra düzenli aralıklarla takibini önerir. Risk altında olduğu saptanan hastaların nutrisyonel değerlendirmeye tabi tutulması gerektiğini belirtir. Malnütrisyonu tanı ve sinıflandırılması tedavi açısından önemlidir. Malnutrisyon sınıflamalarından biri olan inflamasyonun eşlik ettiği malnutrüsyon tipi, altta yatan hastalığın yol açtığı anoreksi ve doku yıkımı ile karakterize katabolik durumdur. Anoreksi, azalmış besin alımı, vücut ağırlık kaybı ve kas katabolizmasına yol açan inflamatuvar yolaklar altta yatan hastalıklarla ilişkili olduğu için inflamasyonu tetikleyen faktörler hastalığa özgüdür. Malnütrisyonda, negatif enerji dengesi ve farklı derecelerde inflamatuvar aktivitelerin bir arada olması vücut kompozisyonunun değişmesine, işlevlerin azalmasına neden olur. Bununla birlikte malnutrisyon, morbidite, mortalite, ekonomik yük, hastanede yatış süresi ve sıklığını, yaşam kalitesinin azalmasını arttırmaktadır $(26,28)$. 
DAÜ’lü hastaların \%84.8'inin beslenme durumu bozulmuştur. DAÜ'nün şiddeti ve bununla ilişkili inflamatuvar yanıt, besin ögesi eksikliklerini şiddetlendiren negatif protein metabolizmasıyla ilişkilidir (29-31). Beslenme desteğine olan ihtiyacın belirlenmesi amaciyla beslenme durumunun saptanması ve enerji alımı, makro ve mikro besin ögesi eksikliklerinin beslenme desteği ile karşılanması yara iyileşmesini ve organları koruma sürecini olumlu etkilemektedir (32).

Bir çalışmada, mini nutrisyonel değerlendirme (Mini Nutritional Assessment [MNA]) ile beslenme durumunu değerlendirilen DAÜ'lü bireylerin \%70.5'inde malnütrisyon riski saptanmıştır. MNA skorlarının alt ekstremite ampütasyon (AEA) şiddetinin artmasıyla azaldığı dolayısı ile MNA skoru ile AEA riski arasında negatif bir ilişkili olduğu bildirilmiştir. MNA skorundaki her bir birim azalma ile majör AEA riskinin \%23, minör AEA riskinin \%11 arttığı gösterilmiştir. Araştırmacılar tarafindan, bu popülasyonun beslenme durumunun değerlendirilmesinde MNA'nın kullanılması önerilmiştir (32).

\section{Enerji ve Besin Ögesi Gereksinimi}

Enerji gereksinimi: Enerji anabolizma, nitrojen sentezi, kollajen oluşumu ve yara iyileşmesi için gereklidir. Glukoz, kollajen sentezi için majör yakıt kaynağıdır. Yaş, cinsiyet, komorbidite, aktivite, hastalık, stres faktörü ve şiddeti, yara sayısı, büyüklüğü enerji ihtiyacını belirleyen faktörlerdir. İyileşme süreci, hücre proliferasyonu, protein sentezi ve enzim aktivitelerindeki artış enerji ve protein gibi substratları gerektirmektedir (21). Avrupa Basınç Ülseri Danışma Paneli (The European Pressure Ulcer Advisory Panel [EPUAP]) ve Ulusal Bası Ülseri Danışma Paneli (The National Pressure Ulcer Advisory Panel [NPUAP])'nin, bası ülseri olan yetişkinler için enerji gereksinimini 30-35 kkal/kg/gün olarak önerdiği bildirilmiştir. Ayrıca, NPUAP’ın ideal vücut ağırlığının altında olan veya ağırlık kaybeden hastalar için enerji gereksiniminin 35-40 kkal/kg/gün olacak şekilde arttırılmasını önerdiği de belirtilmiştir $(33,34)$.
Erken beslenme müdahalesi protein ve enerji gereksinimindeki yetersizlikleri, bu yetersizliklerin bası ülseri riski ve iyileşmesi üzerindeki olumsuz etkilerini önleyerek veya geciktirerek yağsız vücut rezervlerini destekler. Uzun sürede kaybedilen yağ kütlesi ve yağsız doku kütlesinin korunması tüm müdahalelerde çok önemlidir (33-35). 33,34.35).

Protein: Yara iyileşme sürecini etkileyen önemli besin ögelerindendir. Yara iyileşmesini içeren enzimlerin sentezi, hücre proliferasyonu ve kollajen bağ doku oluşumu için gereklidir. Pozitif nitrojen dengesi için yeterli miktarda protein yara iyileşmesinin tüm safhalarında gereklidir. Yara infeksiyonu varlığında yağsız vücut kütlesinin depolarını korumak için protein ihtiyacı artar. Protein alımının artması yara iyileşme oranını arttırır. Yaranın tipi ve şiddetine ve yaranın durumuna göre protein kaybı değişebilir. Örneğin bası ülserlerinde evre 3 ve 4'te daha fazla protein kaybı vardır. Kronik yarası olan ve negatif basınç tedavisi alan hastalarda sürekli drenaj sistemi yüzünden protein kaybı riski artmıştır ve protein ile zenginleştirilmiş oral besin desteği verilmelidir (36). Protein alımı 1.25-1.5 g/kg/gün olarak önerilmektedir. Hastada şiddetli katabolizma var ise önerilen protein alım miktarı 1.5-2 g/kg/gün olabilir. Bununla birlikte $2 \mathrm{~g}$-/kg/gün protein verildiğinde dehidrasyon ve renal yük göz önünde bulundurulmalı ve izlenmelidir. Enerji gereksinimini karşılamak için proteinlerin kullanımını önlemek amacıyla yeterli enerji verilmelidir. Kas dokusunda protein sentezinin sağlanması için protein alımının öğün başına dağılımının 25-30 g olması önerilmektedir. Protein gereksiniminin yanı sıra aminoasit gereksinimi de önemlidir. Arginin ve glutamin yara iyileşmesinde önemli rolü olan iki aminoasittir (37).

Arginin: İnflamasyonda esas olan nitrik oksit için öncüdür ve kollajen üretiminde de kullanılır. Akut yarada doku gerilimini iyileştirir. Kas ve bağ dokusu kütlesini sürdürmek için yeterli arginin olmasına karşın stres veya yaralanmada vücut depoları hızla azaldığından yara iyileşmesinde hastalık stresine bağlı olarak ek arginin takviyesi önerilir. Arginin standart tüple beslenme ürünlerinde (yaklaşık 2.4-5.4 
g/gün) bulunur. Arginin eklenmiş enteral beslenme ürünlerinde ise 12.5-18.7 g/L bulunur ve çalışmalar oral arginin desteğinin (17-30 g/gün) yara iyileşmesinde yararlarını göstermiştir ancak kronik yara iyileşmesindeki rolü kesin olarak tanımlanmamıştır ve güvenilir dozu kesinlik kazanmamıştır $(37,38)$. Argininin alt ekstremite amputasyonunu önlediği ve diyabetlilerde kronik ülserin iyileşme zamanına olumlu etkileri olduğu çalışmalarda gösterilmiştir (39).

Glutamin: Plazmada en bol bulunan aminoasittir ve hücre nükleotidlerinin donörüdür. Protein sentezinin uyarılmasını ve bağışıklık fonksiyonunun desteklenmesini sağlar. Kollajen oluşumunda da etkindir. Yaralanmalar sonrası glutamin seviyeleri kaslarda hızla düşer bununla birlikte glutaminin yara iyileşmesindeki direkt etkisi gösterilememiştir. Ancak deneysel çalışmalarda yara infeksiyonunu azalttığı ve yara iyileşmesine katkıda bulunduğu ile ilgili sonuçlar bulunmaktadır. ESPEN'e göre kritik travmalı hastada ilk beş gün 0.2-0.3 g/kg/gün glutamin önerilir, ancak kronik yara iyileşmesinde 10-15 gün gibi bir sürede kullanılmalıdır (40).

Yağ: Prostoglandinler hücre metabolizması ve inflamasyonda major rol oynar ve prostoglandin sentezi diyette bulunan linoleik ve araşidonik aside bağlı olduğundan yetersizliği, yara iyileşmesini bozar. Omega-3 (n-3) yağ asitlerinin eklenmesi immün fonksiyonu iyileştirir, infeksiyon oranını azaltır ve yaşam süresini arttırır (37). DAÜ'lülerde 12 hafta n-3 yağ asidi takviyesi, metabolik profil üzerinde iyileştirici etkileriyle yara iyileşmesinde rol oynamış, ülserin uzunluğu, genişliği ve derinliğinde anlamlı iyileşmelere neden olduğu gösterilmiştir (41).

Dehidrasyon: Dehidrasyon malnütrisyon ile birlikte, yaygın ve az tanınan bir problemdir. Yara dokusunun oksijenlenmesi için gereklidir. Hiperbarik oksijen tedavisi ve yeterli hidrasyon kronik yara iyileşmesinde önemlidir. Tüketilmesi önerilen miktar $30 \mathrm{~mL} / \mathrm{kg}$ ya da 1-1.5 mL/kkal'dir (42,43).

\section{Vitamin ve Minerallerin Yara İyileşmesindeki Rolü}

Mikro besin ögelerinin DAÜ için belirgin yararları vardır. Vitamin ve minerallere, muhtemelen yara yoluyla ve/veya doku onarımı ve rejenerasyon ile gereksinim artmaktadır. Bası ülseri olan ya da gelişme riskiolan bireylerde vitamin-mineraliçeren dengelibir diyetin alımı diyetisyen tarafından değerlendirilmeli ve hastalar bu konuda desteklenmelidir (44).

Yara iyileşmesinde nekrotik dokunun çıkarılması, bakterilerin inaktivasyonu, iyileşen iltihaplanma aşamasında yüksek seviyelerde serbest radikal üretimi artar. Antioksidanlar (A, C ve E vitamini ve selenyum) serbest radikalleri nötralize etmesi ve rejeneratif dokuya zarar vermemesi nedeniyle tercih edilmelidir (45).

A vitamini: İnflamatuvar fazda monosit ve makrofaj sayısını arttırır, immün sistemi uyarır. Fibroblastlarla kollajen depolamayı arttırır, epitelizasyonu uyarır, yara iyileşmesini arttırır. Yara iyileşmesinde kortikosteroidlerin antiinflamatuvar etkisini tersine çevirir. Hastalık stresi ve ciddi yaralanmalarda A vitamini yetersizliği görülmüştür. Eksikliğinde kollajen sentezi ve re-epitelizasyonu geciktirmekte, infeksiyonlara yatkınlığı arttırmaktadır. Diyet referans değeri (Dietary Referans Intake [DRI]) kadınlar için $700 \mu \mathrm{g} / \mathrm{gün}$, erkekler için $900 \mu \mathrm{g} /$ gündür. Yara iyileşmesi için 10 gün boyunca 10 000-50 $000 \mathrm{IU} /$ oral veya $10000 \mathrm{IU}$ intra muscular (im) önerilmektedir. A vitamini suplementasyonu ile inflamatuvar aktiviteye karşı reaktive olabilir bu yüzden öneriler dikkatli yapılmalıdır. Topikal uygulaması, steroidlerin kronik yaralar üzerindeki etkilerini tersine çevirmeye yardımcı olmak için klinik olarak etkili olabilir. Yara iyileşmesinde kullanım için spesifik doz belirlenmemiştir $(34,38,46,47)$.

c vitamini: Kollajen oluşumunda immün modülasyonu ve antioksidan fonksiyonları sağlar. Yetersizliğinde ise, proliferatif ve remodelling sırasındaki artmış kapiller frajilite, azalmış kollajen gerilme kuvveti, inflamasyonda bozulmuş immün yanıtı oluşturmaktadır. C vitamini yetersizliğinde ya da evre 1 ve evre 2 ülserlerde önerilen $C$ vitamini 
miktarı 100-200 mg/gündür. Bu düzeyin evre 3 ve evre 4'de ise (bası yara, şiddetli travma) $1000-2000 \mathrm{mg} /$ gün olması önerilmektedir $(47,48)$.

D vitamini: Wagner'e göre evre 3 yarası bulunan 60 DAÜ’lü ile yapılmış bir çalışmada (49), on iki hafta boyunca yapılan D vitamini takviyesinin, glukoz homeostazisi, total-LDL-kolesterol, total-/ HDL-kolesterol, hs-CRP seviyeleri üzerinde antiinflamatuvar ve antioksidan olarak yararl etkileri olduğu gösterilmiştir. D vitamininin iyileşmiş glisemik kontrol üzerindeki etkisi ile yara iyileşmesinde dolaylı bir rol oynadığı da gösterilmiştir (49).

E vitamini: Diyabetik farelerde, topikal uygulamanın oksidatif stresi azalttığı, kollajen içeriğini arttırarak iyileşmede anlamlı değişikliklere neden olduğu gösterilmiştir (50).

Magnezyum (Mg): Protein ve kollajen yapımı ve doku gelişimi için gerekli enzimler için kofaktör olarak görev alan önemli bir eser elementtir. Adenozintrifosfat (ATP) ile etkileşime girerek yara iyileşmesi sırasındaki kollajen sentezini destekler. Düşük Mg alımı DAÜ ile ilişkili bulunmuştur. On iki hafta $\mathrm{Mg}$ takviyesi alan DAÜ'lülerde, ülser boyutu, glukoz metabolizması, serum hs-CRP düzeyi üzerinde Mg takviyesinin olumlu etkileri olduğu gösterilmiştir $(51,52)$.

Çinko (Zn): Hücre metabolizmasında yer alan elzem bir mineraldir. DNA sentezi, protein, kollajen sentezinde, hücre proliferasyonunda, immün fonksiyonda önemli rol oynar. Zn suplementasyonu yalnızca yaygin olarak PEM, diyare, malabsorpsiyon, hipermetabolik durumlarda, yetersizliğinde önerilir.

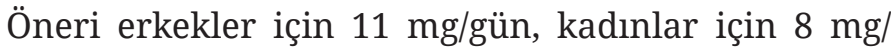
gündür. Yara iyileşmesinde $40 \mathrm{mg} /$ güne kadar (10 gün) çıkılabilir. Diyabetik ayak yarası olan hastada Zn suplementasyonunun ülser ve metabolik parametreler üzerine olumlu etki gösterdiği bildirilmiştir (47).

DAÜ’sü olan 270 hastanın dahil edildiği çift körlü randomize bir çalışmada arginin, glutamin ve beta-hidroksi-beta-metilbutirat (HMB) on altı hafta boyunca günde iki kez verilmiştir. Gruplar arasında yara iyileşme ve kapanması süresinde anlamlı fark bulunamamıştır ancak albümin düzeyi <40 g/L ve/ veya Anckle -brakiyal indeksi $<1.0$ olan bireylerde, besin desteği alan grupta kontrol grubuna göre on altı haftada anlamlı olarak iyileşme görülmüştür. Standart tedaviye ek olarak arginin, glutamin ve HMB ilavesi albümin ve anckle brakiyal indeksi olumlu etkileyerek DAÜ’yü olumlu etkileyebileceği düşünülmüştür (53). HMB iskelet kasında üretilen bir lösin metabolitidir. Lösin'in \%5’i kas hücrelerinde HMB'a metabolize olduğundan, yaşlllarda takviye gereklidir. İn vitro koşullarda yapılan çalışmada, HMB'nin; kas kaybının tedavisinde miyogenezin artmasında, kas apoptozunun azalmasinda ve kas proteini döngüsünü pozitif etkilemesinde rolü vardır. HMB yaşlılarda kas kütlesini, gücünü arttırmak için etkili gibi görünmektedir. Önerilen doz $3 \mathrm{~g} /$ gündür. HMB, besin olarak sadece greyfurt, avokado, kuşkonmaz ve yayın balığı gibi besinlerde çok az miktarda bulunur $(54,55)$.

\section{Yara İyileşmesinde Glisemik Kontrolün Önemi}

Johns Hopkins'de yapılan çalışmada; A1c düzeyi ile yara iyileşme oranı arasında önemli ölçüde bir ilişkili olduğu bulunmuştur (56). Kötü glisemik kontrol ile infeksiyona duyarlı DAÜ oluşabilir. Yüksek kan glukoz düzeyleri, inflamatuvar göstergelerin üretimini etkileyebilir, kollajen sentezini engelleyebilir, hücresel morfolojiyi değiştirebilir (57). A1c düzeyi ile yaranın iyileşme oranı arasındaki ilişkiyi değerlendiren bir çalışma da A1c'deki her \%1.0 artış ile yara alanındaki iyileşmenin günde $0.028 \mathrm{~cm}$ azaldığı ve bu azalmanın istatistiksel olarak anlamlı olduğu gösterilmiştir. Araştırmacılar, çalışma bulgularının, DAÜ’lülerde yara iyileşme oranını tahmin etmede A1c'nin önemli bir biyobelirteç olabileceğini düşündürdüğünü ifade etmişlerdir (56).

Çin'deki DAÜ’lü 669 hastada amputasyon insidansı ve klinik olarak ilişkili risk faktörlerini belirlemek amacıyla yapılmış kohort çalışmada demografik bilgi, tıbbi ve sosyal öykü verileri incelenmiştir. Çalışmada nöropati taraması, periferik arter hastalığg taraması, beslenme durumu ve glisemik kontrol 
değerlendirmesi, ayak deformitesi dahil olmak üzere tüm muayeneler yapılmıştır. Gangren, infeksiyon, Wagner dereceleri, diyabet süresi, biyokimyasal parametreler ve major ampütasyon varlığı değerlendirilmiştir. Araştırmacılar, erken evrelerde diyabetik hastalarda iyi metabolik yönetimin önemini vurgulamış ve DAÜ’nün teşhisini takiben daha yoğun sürveyans ve agresif tedavi ile düzeltilebileceğini bildirmişlerdir (58).

Plasebo kontrolü, randomize kontrollü bir çalışmada, 40-85 yaş aralığında DAÜ'lü (evre 3) 60 hastaya laktobasillus asidofilus, laktobasiillus casei, laktobasillus fermantum, bifidobakterium bifidum içeren probiyotik takviyesi verilmiştir. Önerilen doz sağlıklı yetişkinlere göre düzenlenmiştir. On iki hafta probiyotik takviyesinin ülser büyüklüğü, glisemik kontrol, hs-CRP, plazma nitrik oksit, total antioksidan kapasite ve malondialdehid seviyeleri üzerinde faydalı etkileri olduğu gösterilmiştir (59). Besin ögesi takviyelerinin yara iyileşmesini destekleyebileceği bildirilmektedir (20,60). Besin ögesi takviyesinin glisemik kontrol üzerinde muhtemel dolaylı bir etkisi olabilir ancak bu konuda yapılmış kapsamlı çalışmalara gereksinim vardır.

\section{SONUÇ VE ÖNERILER}

DAÜ’ler hastanın yaşam kalitesini önemli ölçüde azaltabilir, hastaneye yatış sıklığını arttırabilir, infeksiyon ve kangren nedeni ile amputasyona neden olabilir. DAÜ’lü bireylerin beslenme durumunun iyileştirilmemesi bağışıklık sistemini ve glisemik kontrolü olumsuz etkileyerek yara iyileşmesini geciktirir. DAÜ’yü tedavi etmek için kanıta dayalı bir kılavuz bulunmamakla birlikte NPUAP, basınç ülserlerinin önlenmesi ve tedavisi için kanıta dayalı beslenme önerileri geliştirmiştir. NPUAP’ın beslenme önerileri yara iyileşmesini desteklemek için mikro ve makro besin ögelerinin alım düzeylerinin arttırılmasına odaklanmıştır. Çeşitli besin ögelerinin yara iyileşmesi üzerindeki etkisi, deneysel çalışmalarla gösterilmiştir ancak kllavuzlarda yer almamaktadır. Bununla birlikte besin ögesi takviyeleri ile yara iyileşmesinin desteklenebileceği bildirilmektedir. Sonuç olarak, yeterli enerji, protein, vitamin ve mineral alımının sağlanması DAÜ’nün iyileşmesinde etkilidir. DAÜ'lü hastalar besin değeri açısından yoğun olan besinleri içeren sağlıklı bir beslenmeye teşvik edilmelidir.

Çıkar çatışması - Conflict of interest: Yazarlar çıkar çatışması olmadığını beyan ederler. - The authors declare that they have no conflict of interest.

\section{KAYNAKLAR}

1. Tatti P, Barber A. Nutritional Treatment of DiabeticFoot Ulcers - A Key to Success. In: Dinh T, ed. Global perspective on diabetic foot ulcerations, 2011, p:202-216

2. IDF Diabetes Atlas Eighth Edition 2017. ISBN: 978-2930229-87-4

3. Çetinkalp Ş. Diyabetik Ayak. (Ed. Çetinkalp §̧). Endokrinoloji 1.Baskı. Türkiye Klinikler Yayınevi Ankara, 2017.s.464-481.

4. Zhang SS, Tang ZY, Fang P, Qian HJ, Xu L, Ning G. Nutritional status deteriorates as the severity of diabetic foot ulcers increases and independently associates with prognosis. Expl Ther Med 2013;(5)1:215-22.

5. Altındaş M, Yara İyileşmesi, Available at: http://www.ctf. edu.tr Accessed: June 22, 2019.

6. Kurt İ. Glikozile hemoglobin ölçümü ve diabetes mellitusun uzun dönem glisemik kontrolünde kullanılması. Gülhane Tıp Dergisi. 2003;45(4):387-95.

7. MacKay D, Miller AL. Nutritional support for wound healing. Alter Med Rev. 2003;8(4):359-77.

8. Samancıoğlu S. Diyabetik Ayakbakimi İçin Preklinik Çalişma:DeneyselDiyabet ModeliGeliştirilmişsiçanlarda Oluşturulmuş İskemik Yara Bakiminda Klasik Yara Pansuman Materyali İle Zeytin Yapraği Ekstresinin Karşilaştirilmasi. Ege Üniversitesi, Sağllk Bilimleri Enstitüsü, İç Hastalıkları Hemşireliği Anabilim Dalı Doktora Tez, İzmir, 2013.

9. Nursal TZ, Baykal A, Hamaloğlu E. Yaşlllarda yara iyileşmesi: fark var mı? Turki J Geriatr 1999;2(1):29-32.

10. Gurtner G.Woundhealing: Normal and abnormal; Grabb and Smith's Plastic Surgery. 6th edition. LippincottRaven Publishers, Philadelphia 2007. p.15-22.

11. American Diabetes Association. Consensus development conference on diabetic foot wound care. Diabetes Care. 1999;22(8):1354-60.

12. Berk A, Dokumacı AH, Kaymaz MB. Yara iyileşmesi ve diyabetik yara tedavisinde kullanılan tıbbi bitkiler. Sağlık Bilim Derg. 2015;24(3):185-92. 
13. Türsen Ü. Ülser tedavisinde yara örtüleri. Turk J Dermatol. 2013;7:61-71.

14. Saygın H. Basınç yaralarında hemşirelik yönetimi. İç Hastalıkları Dergisi. 2008;15(3):141-44.

15. Arslan MK. Yara iyileşmesi ve iyileşmeyi engelleyen faktörler. Kurt N (editör). Akut ve Kronik Yara Bakımı. Nobel Tip Kitapevleri 2003:9-33.

16. Akan KH. Diyabetik ayakta ampütasyon. TOTBİD Dergisi. 2015; 14:421-32

17. Prompers L, Huijberts M, Schaper N, Apelqvist J, Bakker K, Edmonds M, Holstein P, Jude E, Jirkovska A, Mauricio D, Piaggesi A, Reike H, Spraul M, Van Acker K, Van Baal S, Van Merode F, Uccioli L, Urbancic V, Ragnarson Tennvall G. Resource utilisation and costs associated with the treatment of diabetic foot ulcers. Prospective data from the Eurodiale Study. Diabetologia. 2008;51:1826-34.

18. Blume $\mathrm{P}, \mathrm{Wu}$ S. Updating the diabetic foot treatment algorithm: recommendations on treatment using advanced medicine and therapies. Wounds. 2018;30(2):29-35.

19. National Pressure Ulcer Advisory Panel, European Pressure Ulcer Advisory Panel and Pan Pacific Pressure Injury Alliance. Prevention and Treatment of Pressure Ulcers: Quick Reference Guide. Emily Haesler (Ed.)2014. Cambridge Media: Osborne Park, Australia. 2014.p.201.

20. Vas PRJ, Edmonds ME, Papanas N. Nutritional supplementation for diabetic foot ulcers: the big challenge. Int J Low Extrem Wounds. 2017;16(4):226-9.

21. Şanlıer N, Yassıbaş E. Yara iyileşmesinde beslenmenin önemi. (Eds. Tayfur M. Ayhan YN). Beslenme ve Diyetetik. Güncel Konular 1,1. baskı. Hatipoğlu Basın ve Yayım San.Tic. Ltd. Şti, Ankara 2015. 5;139-58.

22. Ozkalkanli MY, Ozkalkanli DT, Katircioglu K, Savaci S. Comparison of tools for nutrition assessment and screening for predicting the development of complications in orthopedic surgery. Nutr Clin Pract. 2009;24:274-80.

23. Raffaitin C, Lasseur C, Chauveau P, Barthe N, Gin H, Combe C, Rigalleau V. Nutritional status in patients with diabetes and chronic kidney disease: a prospective study. Am J Clin Nutr. 2007;85:96-101.

24. Ghanassia E, Villon L, Thuan Dit Dieudonné JF, Boegner C, Avignon A, Sultan A. Long-term outcome and disability of diabetic patients hospitalized for diabetic foot ulcers. A 6.5-year follow-up study. Diabetes Care. 2008;31:1288-92.

25. Dağ B. Nutrisyon durumunun değerlendirilmesi. (Eds. Erdem NZ, Gümüşel S) TDD Nutrisyonda Güncel Konular.2011.s.9-33.

26. Cederholma T, Barazzoni R, Austin P, Ballmer P, Biolo G, Bischoff SC, Compher C, Correia I, Higashiguchi T, Holst M, Jensen GL, Malone A, Muscaritoli M, Nyulasi I,
Pirlich M, Rothenberg E, Schindler K, Schneider SM, de van der Schueren MA, Sieber C, Valentini L, Yu JC, Van Gossum A, Singer P. ESPEN guidelines on definitions and terminology of clinical nutrition. Clin Nutr. 2017;36:4964.

27. Cederholm T, Bosaeus I, Barazzoni R, Bauer J, Van Gossum A, Klek S, Muscaritoli M, Nyulasi I, Ockenga J, Schneider SM, de van der Schueren MA, Singer P.Diagnostic criteria for malnutrition an ESPEN consensus statement. Clin Nutr. 2015;34:335-40.

28. White JV, Guenter P, Jensen G, Malone A, Schofield M; Academy Malnutrition Work Group; A.S.P.E.N. Malnutrition Task Force; A.S.P.E.N. Board of Directors. Consensus statement: Academy of Nutrition and Dietetics and American Society for Parenteral and Enteral Nutrition: characteristics recommended for the identification and documentation of adult malnutrition (undernutrition). JPEN J Parenter Enter Nutr. 2012;36:275-83.

29. Bauer JM, Vogl T, Wicklein S, Trögner J, Mühlberg W, Sieber CC. Comparison of the mini nutritional assessment, subjective global assessment, and nutritional risk screening (NRS 2002) for nutritional screening and assessment in geriatric hospital patients. Z Gerontol Geriatr. 2005 Oct;38(5):322-7.

30. Brem H, Tomic-Canic M. Cellular and molecular basis of wound healing in diabetes. J Clin Invest. 2007;117(5):1219-2.

31. İnanç N, Çiçek B. Beslenme Desteği: Endikasyon ve Etkinlik. (Eds: Besler T,İnanç N) Diyetisyen El Kitabı. Enteral ve Parenteral Nutrisyon. 2014, p.22-45.

32. Gau BR, Chen HY, Hung SY, Yang HM, Yeh JT, Huang CH, Sun JH, Huang YY. The impact of nutritional status on treatment outcomes of patients with limb-threatening diabetic foot ulcers. J Diabetes Complications. 2016;30:138-42.

33. Litchford MD, Dorner B,Posthauer ME. Malnutrition as a precursor of pressure ulcers. Adv Wound Care (New Rochelle). 2014;1;3(1):54-63.

34. Thompson C, Fuhrman MP, Nutrients and wound healing: still searching for the magic bullet. Nutr Clin Pract. 2005;20:331-47

35. Dorner BME, Thomas D. The Role of Nutrition in Pressure Ulcer Prevention and Treatment: National Pressure Ulcer Advisory Panel Nutrition White Paper. Advances in Skin \& Wound Care.2009; 22(5):212-221

36. Kenneth B. Rehm. Nutritional aspects of healing a diabetic foot wound. Podiatry Management 2003;199208.

37. Arnold M, Barbul A. Nutrition and wound healing. Plast Reconstr Surg. 2006;117 (7 Suppl):42-58.

38. Stechmiller JK. Understanding the role of nutrition and 
wound healing. Nutr Clin Pract.2010;25(1):61-8.

39. Arana V, Paz Y, González A, Méndez V, Méndez JD. Healing of diabetic foot ulcers in L-arginine-treated patients. Biomed Pharmacother. 2004;58(10):588-97.

40. Singer P, Blaser AR, Berger MM, Alhazzani W, Calder PC, Casaer MP, et al. ESPEN guideline on clinical nutrition in the intensive care unit. Clin Nutr. 2019;38: 48-79.

41. Soleimani Z, Hashemdokht F, Bahmani F, Taghizadeh M, Memarzadeh MR, Asemi Z. Clinical and metabolic response to flaxseed oil omega-3 fatty acids supplementation in patients with diabetic foot ulcer: A randomized, double-blind, placebo-controlled trial. J Diabetes Complications. 2017;31(9):1394-1400.

42. Johnston E. The Role of nutrition in tissue viability. Wound Essentials. 2007;2:10-21.

43. Posthauer M. Hydration: an essential nutrient. Adv Skin Wound Care. 2003;18(1): 32-3.

44. Kulprachakarn K,Ounjaijean S,Wungrath J, Mani R, Rerkasem K. Micronutrients and natural compounds status and their effects on wound healing in the diabetic foot ulcer. Int J Low Extrem Wounds. 2017;16(4):244-50.

45. Parenteral and Enteral Nutrition Group of the British Dietetics Group (PENgroup). A pocket guide to clinical nutrition. 3rd edition, British Dietetic Association, Birmingham, UK, 2004

46. Arnold M, Barbul A. Nutrition and wound healing. Plast Reconstr Surg. 2006;117(7): 42S-58.

47. Molnar JA,1, Underdown MJ, Clark WA. Nutrition and chronic wounds. Adv Wound Care (New Rochelle). 2014.1;3(11):663-81.

48. Seifried HE, Anderson DE, Fisher EI, Milner JA. A review of the interaction among dietary antioxidants and reactive oxygen species. J Nutr Biochem. 2007;18:567-79.

49. Razzaghi R,Pourbagheri H,Momen-Heravi M, Bahmani F, Shadi J, Soleimani Z, Asemi Z.The effects of vitamin $\mathrm{D}$ supplementation on wound healing and metabolic status in patients with diabetic foot ulcer: A randomized,double-blind, placebo-controlled trial. J Diabetes Complications. 2017;31:766-72.

50. Galeano M, Torre V, Deodato B, Campo GM, Colonna M, Sturiale A, Squadrito F, Cavallari V, Cucinotta D, Buemi M, Altavilla D. Raxofelast, a hydrophilic vitamin E-like antioxidant, stimulates wound healing in genetically diabetic mice. Surgery. 2001;129:467-77.
51. Keşkek şÖ, Kırım S, Karaca A, Saler T. Low serum magnesium levels and diabetic foot ulcers. Pak J Med Sci. 2013;29(6):1329-33.

52. Rodríguez-Morán M, Guerrero-Romero F. Low serum magnesium levels and foot ulcers in subjects with type 2 diabetes. Arch Med Res. 2001;32(4):300-3.

53. Armstrong DG, Hanft JR, Driver VR, Smith AP, LazaroMartinez JL, Reyzelman AM, Furst GJ, Vayser DJ, Cervantes HL, Snyder RJ, Moore MF, May PE, Nelson JL, Baggs GE, Voss AC; Diabetic Foot Nutrition Study Group. Effect of oral nutritional supplementation on wound healing in diabetic foot ulcers: a prospective randomized controlled trial. Diabet. Med. 2014;31:1069-77.

54. Rossi AP, D'Introno A, Rubele S, Caliari C, Gattazzo S, Zoico E, Mazzali G, Fantin F, Zamboni M.The potential of $\beta$-hydroxy- $\beta$-methylbutyrate as a new strategy for the management of sarcopenia and sarcopenic obesity. Drugs Aging. 2017;34(11):833-40.

55. Wu H, Xia Y, Jiang J, Du H, Guo X, Liu X, Li C, Huang G, Niu K. Effect of beta-hydroxy-beta-methylbutyrate supplementation on muscle loss in older adults: a systematic review and meta-analysis. Arch Gerontol Geriatr. 2015;61(2):168-75.

56. Christman AL, Selvin E, Margolis DJ, Lazarus GS, Garza LA. Hemoglobin A1c predicts healing rate in diabetic wounds. J Invest Dermatol.2011;131(10):2121-7.

57. Tsourd E, Barthel A, Rietzsch H, Reichel A, Bornstein SR. Current aspects in the pathophysiology and treatment of chronic wounds in diabetes mellitus. Biomed Res Int. 2013;2013:385-641.

58. Jiang Y, Ran X, Jia L, Yang C, Wang P, Ma J, Chen B, Yu Y, Feng B, Chen L, Yin H, Cheng Z, Yan Z, Yang Y, Liu F, $\mathrm{Xu} \mathrm{Z}$. Epidemiology of type 2 diabetic foot problems and predictive factors for amputation in China. Int J Low Extrem Wounds. 2015;14(1):19-27.

59. Mohseni S,Bayani M,Bahmani F, Tajabadi-Ebrahimi M, Bayani MA, Jafari P, Asemi Z. The beneficial effects of probiotic administration on wound healing and metabolic status in patients with diabetic foot ulcer: A randomized, double blind, placebo-controlled trial. Diabetes Metab Res Rev. 2018;34(3):e2970.

60. Campos ACL, Groth AK, Branco AB. Assessment and nutritional aspects of wound healing. Curr Opin Clin Nutr Metab Care. 2008;11:281-8. 